\title{
Identidades reflexivas en la universidad: sonidos, imágenes y microrrelatos autobiográficos
}

\section{Reflexive Identities at University: Sounds, Images and Autobiographical Micro-Tales}

\author{
Isabel María Ayala Herrera ${ }^{1}$ \\ imayala@ujaen.es \\ Virginia SÁnchez López \\ vsanchez@ujaen.es \\ Universidad de Jaén, España
}

\section{Resumen:}

La presente investigación tiene como objetivo la búsqueda de nuevas formas de generar e integrar identidades en el aula usando el potencial pedagógico y creativo del microrrelato audiovisionado. Teniendo en cuenta que el currículum oficial y generalista suele silenciar las voces individuales de los estudiantes, para amplificarlas defendemos el uso del método autoetnográfico y la experimentación con los lenguajes narrativo y audiovisual, favoreciendo la interdiscursividad. Estas premisas conceptuales guiaron un proyecto de investigación-acción diseñado como actividad introductoria en una asignatura de música universitaria. Los estudiantes, de diferentes procedencias, intereses y perfiles, participaron en la creación y narración de un microrrelato autobiográfico con dos soportes extraliterarios, música e imagen, en el que indagaron en su imaginario sonoro. El estudio concluye que estas nuevas aproximaciones desde el foco sociocrítico e interpretativo, en combina-
\end{abstract}

\begin{abstract}
:
This paper investigates new ways to generate and integrate identities in the classroom using the pedagogical and creative potential of audiovisual microtales. In light that the official curriculum with its general drive silences the individual voices of students, we defend the use of the auto-ethnographic method and experimentation with both narrative and audiovisual language in favoring interdiscursivity so that students' voices can be amplified. These conceptual foundations were used as a guide in an action research project designed as an introductory activity for a music subject at University. Students from different backgrounds, interests and profiles were invited to lay out the narration of an autobiographical micro-tale with two extra literary supports, music and image, inquiring in their sounds of life. The study concludes that new understandings with an interpretative and socio-critical focus and a qualitative-methodology are highly
\end{abstract}

1 Dirección para correspondencia (correspondence address):

Isabel María Ayala Herrera. Departamento de Didáctica de la Expresión Musical, Plástica y Corporal. Facultad de Humanidades y Ciencias de Educación. Edificio D2, dependencia 145. Universidad de Jaén. Campus Las Lagunillas, s/n. 23071 Jaén (España). 
Identidades reflexivas en la universidad: sonidos, imágenes y microrrelatos

autobiográficos

Isabel María Ayala Herrera y Virginia Sánchez López

ción con la metodología cualitativa, son altamente eficaces a fin de dar respuestas comprometidas que potencian la inteligencia y las capacidades de los estudiantes, favoreciendo la construcción de su identidad y satisfaciendo sus intereses de una manera creativa e integral.

\section{Palabras clave:}

Formación del profesorado de música; microrrelato audiovisionado; construcción de la identidad; imaginarios sonoros; motivación; reflexión e integración en el aula. effective in order to give committed answers that empower the intelligence and capabilities of the students, construct their identity and satisfy their interests in a creative and holistic way.

\section{Key words:}

Music teacher training; audiovisual microtale; student identity; sounds of life (archetypal sounds); motivation; reflection and integration in the classroom.

\section{Résumé:}

Nous nous proposons de rechercher dans cet article de nouvelles manières de générer et d'intégrer des identités dans la salle de classe, tout en utilisant le potentiel pédagogique du micro-récit audio-visionné. Sachant que le cursus officiel et généraliste a tendance à passer sous silence les voix individuelles des étudiants, nous prônons, dans le but de les amplifier, l'usage de la méthode auto-ethnographique et l'expérimentation avec les langages narratifs et audiovisuels, qui favoriseront l'inter-discursivité. Ces prémices conceptuelles ont guidé un projet de recherche-action élaboré comme une activité introductrice dans une matière de musique à l'université. Les étudiants, de différents milieux, intérêts et profils, ont participé à la création et la narration d'un micro-récit autobiographique à deux supports extralittéraires, la musique et l'image, dans lequel ils ont recherché à l'intérieur de leur imaginaire sonore. Notre étude a conclu que ces nouvelles approches, sous un regard sociocritique et interprétatif, combinées avec la méthodologie qualitative, sont hautement efficaces pour donner des réponses engagées qui renforcent l'intelligence et les capacités des étudiants. Le tout, contribuant à la construction de leur identité, et en satisfaisant leurs intérêts de manière créative et intégrale.

\section{Mots clé :}

Formation des professeurs de musique; micro-récit audio-visionné construction de l'identité ; imaginaires sonores; motivation; réflexion et intégration dans la salle de classe.

Fecha de recepción: 16-5-2017

Fecha de aceptación: 27-7-2017

\section{Introduction and Objectives}

The research presented in this essay was developed within the framework of the compulsory subject Musical Education and its Didactics (henceforth MED), offered at the beginning of the first year of the Bachelor's Degree in Primary Education at the University of Jaén. The students usually face this subject with quite a few prejudices, for example, that musical education must only be addressed to specialists, provoking uncertainty and insecurity in an essential moment of their studies. 
From this emerged the necessity of giving a voice to the subject who is learning when faced with the dominant hegemonic discourse and of generating empathies and synergies among the members of the class-group, with different musical approaches and interests, including diametrically opposed ones. At the same time, we were searching for a motivating and captivating function towards the subject itself, based on the students' reflection on paper about sounds in their lives and, by extension, about their existence, concept and position within the university's reality.

To this end, we set as the central activity for students the narration and reading of an autobiographical micro-tale with two extra literary supports shared by the group, music and image, to evoke visual and sound imaginaries that will generate an interdiscursive hypertext.

\section{Method and Background}

Since the present investigation has a qualitative focus, we have employed the ethnographic method, one of the most employed in music education (Odena, 2015). Through this method, it is possible to acquaint with the lifestyle of a society and the relationships established among its members, which, applied to the educational environment and quoting Peter Woods' famous title, allows us to examine "the school from within" (Woods, 1986). Far from the concept of macro-ethnography, referred to as a complex and broad community, our work responds to a micro-ethnography, contributing to the comprehension of educational phenomena inside schooled societies (Rockwell, 1986).

The value of tales, stories of everyday life and other instruments associated to biographical methods in the school context has been put forward in many studies and experiences (Clandinin \& Connelly, 2000; Pujadas, 1992; Yanes, 2007; Sancho et al., 2009; Izquierdo-Magaldi et al., 2014). To this we should add the emerging acceptance of the micro-tale in the last years, a genre linked traditionally to the vanguardist literature and now turned into a true mass phenomenon. This success is probably related with its characteristics of extreme brevity, concision, intensity and, especially, immediacy, that connect with "the busy lifestyle of current societies and the new privileged ways of communication" (Valles, 2008, pp. 53-54), as well as mobile devices (sms, applications like WhatsApp, Line, Hangouts, Telegram, WeChat, Viber, 
Identidades reflexivas en la universidad: sonidos, imágenes y microrrelatos autobiográficos

Isabel María Ayala Herrera y Virginia Sánchez López

Facebook Messenger, Instachat) or the Internet (webs, blogs, forums, chats or social networks like Facebook or Twiteer), inside the so called Cyberculture (Guarinos \& Gordillo, 2010). Together with the transmitter, a new kind of active receiver, typical of transmedia storytelling, who can take part as "immediate critic", appears with the micro-tale (Navarro, 2014). Many agents and schools have taken advantage of this circumstance to introduce micro-tales with different purposes and meaning, even in connection with competitions such as slams or festivals of diverse scope.

Tales and stories of everyday life as methods of biographical research have been addressed in the field of music education from a recent date. In this sense, Jorgensen (2009) has shown particular interest on narrative inquiry in music education; and Jones \& Parkes (2010) analyzed the reasons for the choice of career in music education related to the construction of student's identity. Bond \& Huisman Koops (2014) studied the identity of a beginner teacher of music through narrative inquiry. Kallio (2015), with her "Factional stories", has opened a new and interesting methodological line. In the Latin American context, the research project led by Aguirre (2003) stands out, as well as the Ocaña's doctoral thesis (2006), Ayala \& Castillo's experience (2008) or, more recently, Porta's paper (2014).

These instruments allow us to obtain founded information from the students in order to provide them with a better education. The potential of these texts resides in their power of intra and interpersonal communication, which is basic in the learning-teaching process. Besides describing facts or important situations in the life of the student, they imply a tacit knowledge stemming from the tone of voice, gesture, excuses, silences, sounds, music or images that stand out during their readings or exhibition. In this experience, images and sound give an added value to the tale by generating a new meaning, similar to the one produced in the process of audiovision (Chion, 1993), and creating the opportunity, in the sense of Bautista and Velasco (2011), "to study and to think about the relationship between image and culture, multi-literacy and audiovisual stories to research and to educate ourselves from the personal and group experience $^{\prime 2}$ (cit. by Ballesta, 2012, pp. 353-354). Ultimately, the

2 Own translation of the original Spanish text: "[...] de estudiar y reflexionar sobre la relación entre imagen y cultura, multialfabetización y narraciones audiovisuales para investigar y educarnos desde la vivencia personal y grupal" (cit. en Ballesta, 2012, pp. 353-354). 
student talks openly by sharing his emotions and thoughts with others in order to make them participants, thus connecting with the recent researchers on ego (Díaz \& Giráldez, 2013).

\section{Context and Participants: the Ecosystem of the Classroom}

The research took place during the academic year 2013-2014 with students from University of Jaén (henceforth, UJA) in the framework of the subject MED, a disciplinary subject of 7 credits in Spain (175 hours) positioned at the beginning of the first year of a Bachelor's Degree in Primary Education. From the four existing groups, we selected the one that both authors of this paper were teaching (group C). The class was formed by 60 students, from which 29 were women and 31 were men. The majority of them were included in an age range of 18 to 21 (40 people); 15 were between 22 and 30; 4 were older than 30; and 1 was over 40 .

Regarding the geographical origins, a priori a relevant variable, almost the totality of the students were natives of the province of Jaén $(90 \%)-16$ from Jaén city and 36 from other villages in the area-. Only 6 students came from other Spanish provinces (Alicante, Córdoba, Ciudad Real, Granada), and 2 were from other countries (Erasmus students from Germany and Turkey).

According to the initial analysis of the assessment performed to check the knowledge and skills of students in music and their interest in the subject, the greater part of the group showed only knowledge from mandatory schooling (primary and secondary school); only $12 \%$ of them had received professional music training (conservatory or music schools); and $6 \%$ were amateurs belonging to music bands, associations, choirs and other kinds of music groups. Surprisingly enough, 5\% admitted to not having had access to any musical education in previous programs. When faced with the question of the student body's expectations towards the subject, a considerable percentage of students wished to pass it "pass it" or "get the highest grades"), without bringing up other resolutions like widening their knowledge or developing musical and pedagogical skills. In addition, many of the students considered the subject matter as mere entertainment ("to have fun") more than a curriculum discipline, which contrasted with the professionalizing objective of a minority of students of "to find or confirm a vocation" (see Figure 1a). 
To know and appreciate music and discover new styles To initiate music creation and composition To find or confirm a vocation To learn methodologies and resources for teaching music To develop musical abilities (listening, performing...) To overcome difficulties and to lose one's inhibitions To pass the subject To enjoy yourself, to have fun, to attend dynamic class To get the highest grades To review previous lessons and to deepen knowledge To learn and take advantage of the subject



Figure 1a. Expectations of the Student Body in the Subject MED.

As a previous exercise of self-perception, we were also interested in knowing the musical limitations and potentialities of the student body when confronting the subject. Fear, shyness, 'lack' of ear and a low musical level were the main difficulties confessed. Only a few students manifested being in possession of certain musical skills, like a sense of rhythm or dexterity in musical language (see Figure 1b).

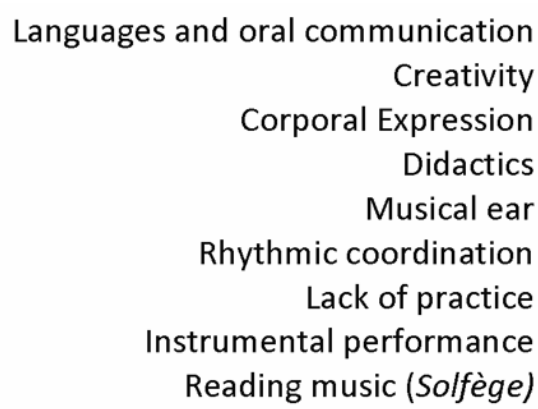

Singing lessons, voice practice, intonation

Low level

Stage fright, shame, shyness, inhibition

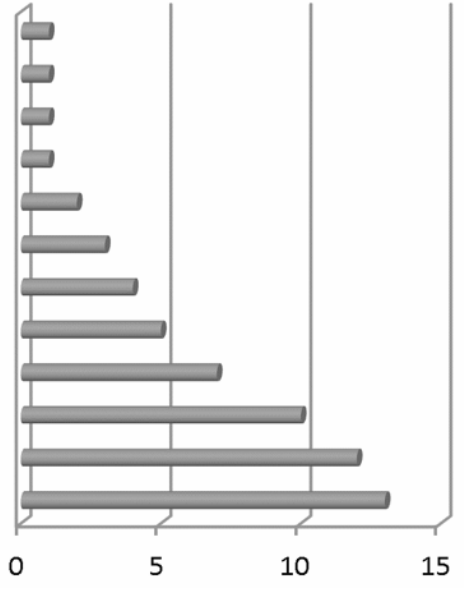

Figure 1b. Possible Difficulties Facing the Subject MED. 


\section{Description}

The research was developed in three phases:

1. Initial evaluation, as described in the previous section, and presentation.

2. Creation of micro-tales and public exhibition.

3. Final thoughts.

As has been previously underscored, the unifying axis was the invention of an individual micro-tale of autobiographical character, supplemented with visual and sound registers, in which the students could narrate in a creative and reflexive way their contact with the musical field.

In the first session, both professors presented their own tales, which revealed sound, musical, and formative referents that had led them to their profession (see Testimony 1 ).

\section{Testimony 1}

I was born in a small village of Jaen province at the end of the seventies. My first sound memory is the engine of a gray Ford coming through Down Street. I don't know why but, from an early stage, music caught me, even more when I joined the newly created Musical Association of my village and their splendid music band; the latter has become the connecting thread for me, not only as a cultural element but as a vital experience [...] (I. A.-H., October $3^{\text {rd }}$ 2013).

Then we asked the students to create their own text (maximum 300 words) to evoke their own sound and visual imaginaries. Neither chronological narration of the depicted facts nor the use of the first person were mandatory, but we did suggest adopting a roughly literary style.

On the other hand, the micro-tale needed to be enriched with extra literary supports, significant music and images that would favour interdiscursivity (Van Dijk, 2003). The images could be photographs from the personal archive, illustrations, collages, newspaper clippings, drawings —among other possibilities — referring to places, objects or people mentioned or suggested in the tale (see Figure 2). 

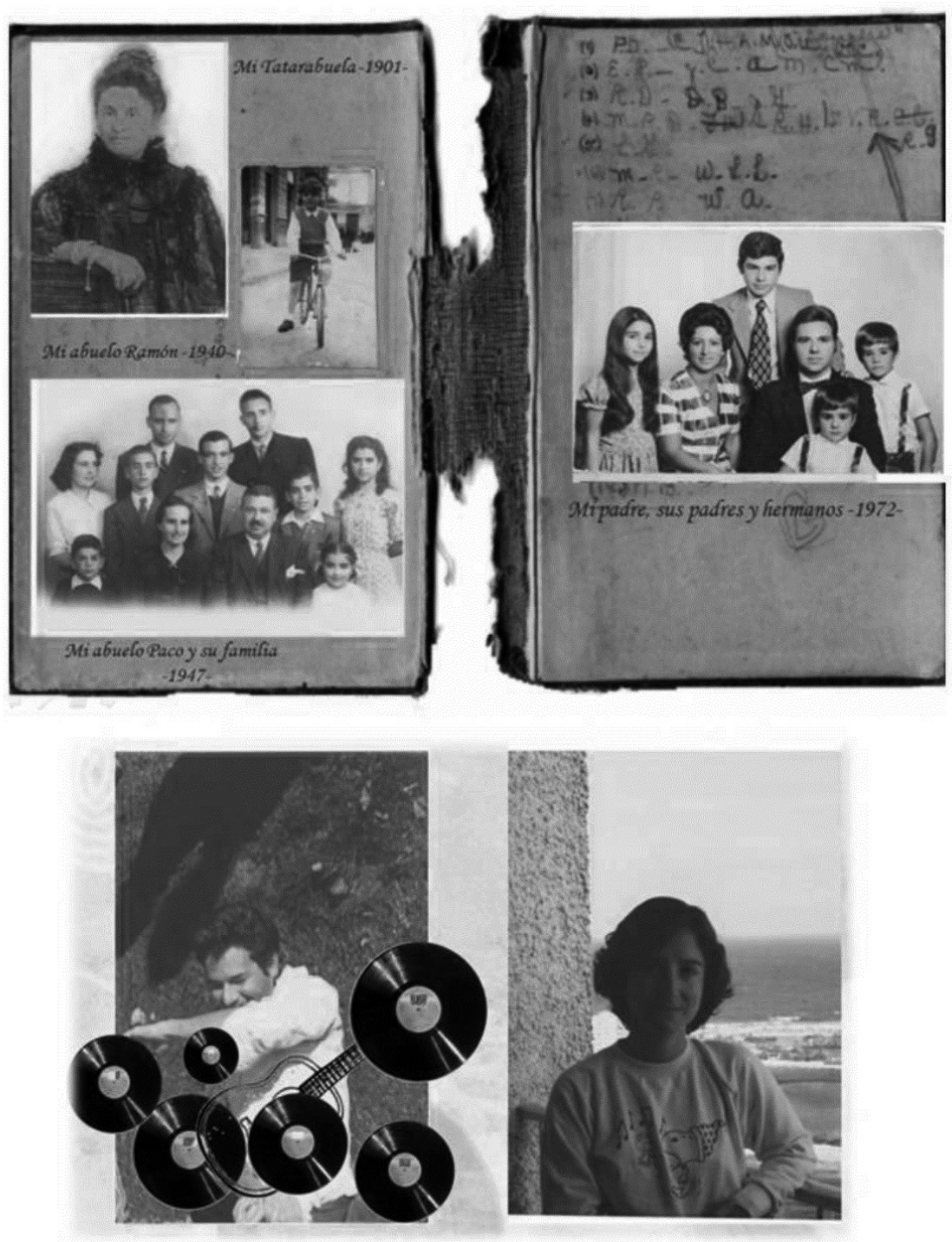

Figure 2. Selection of Images of the Micro-Tale of the Student A. C.-C.

Concerning the sounds, we suggested using recordings of their own voice or of their informers and other human sounds, natural and artificial, collected or downloaded from sound banks such as fragments of musical pieces, manipulated or not, leaving to their judgement the way of integrating them with imagery and text (as a background, the soundtrack of the tale, or alternated as a slideshow) (see Testimony 4, Figure 2 and 
listen Audio 1: Fragment of the narration of the student A. C.-C. Retrieved from https://soundcloud.com/user-674135999/audio-1-fragment-of-thenarration-of-the-student-a-c-c).

The following week, the students presented their tales live in front of their classmates. In addition to the exhibited premises, we assessed positively that the students exploited to the maximum the expressive possibilities of voice and gesture in the reading of their speeches, as well as the possible use of dramatic resources. During this phase, our main evaluation strategy was the observation and hearing of participants. After the round of exhibitions, a group debate was generated as a product of the annotations made by the students during the active listening to the personal stories.

\section{Results}

The audio-viewed tales (final report) reveal the following aspects:

1. The sound imaginaries of the participant student body are quite uniform. Among other coincidences, we highlight: voices of relatives, children's songs, television jingles, film soundtracks, favorite singers, everyday object sounds and new timbres that have emerged with technological development.

2. The majority of students retain in their memories voices, sounds and music associated with very concrete episodes and situations that they sometimes remember in amazing detail. These sounds are exclusive for each student, that is, not shared by the group (see Testimony 2). A significant fact is that a high percentage of these particular sounds is connected to striking personal events, generally negative (see Testimony 3 ).

\section{Testimony 2}

At the age of eight, when I was coming back from school with two neighbors, my mom and my sister were listening to the voice of a woman on the radio, Elena Francis, keeping them very attentive and not allowing us to make any noise during our snack. [...] (A. R.-L, October 10 $\left.0^{\text {th }}, 2013\right)$.

\section{Testimony 3}

I have just come out from an MRI scan and I assure you that I will never forget that set of buzzing, turns and interferences [...] (J.-C. A.-L., October $\left.10^{\text {th }}, 2013\right)$. 
Identidades reflexivas en la universidad: sonidos, imágenes y microrrelatos autobiográficos

Isabel María Ayala Herrera y Virginia Sánchez López

3. The first sound memories are connected to the family and/or the school sphere; some even get carried back to the sound landscape of their previous generations, most of all from parents and grandparents (see Testimony 4, Figure 2 and listen Audio 1).

\section{Testimony 4}

My parents were very musical. My father would play the guitar. He likes music very much. He loves to tell how when he was young, he would save money to buy himself some vinyl records. He has so many records that he has lost count [...]. (A. C.-C., October $8^{\text {th }}, 2013$ ).

4. Musical tastes and preferences of the student body are strongly influenced by means of communication and the discography market, commercial pop music being the preferred style, in line with the results of other studies (Ibarretxe, 2006). During the university phase, the image of the music idol shaped in adolescence persists, even though the artists keep changing depending on the evolution the students' tastes [Testimony 5]. We agree with Martínez-Iglesias (2011) that "students [are] an ensemble of archetypes, founded, assumed or constructed around other stories" (p. 126) and whose musical and visual preferences are strongly based on learning developed outside of the classroom (not formal and informal education).

\section{Testimony 5}

I learnt with my first love that the evolution of Spanish pop was in decay; from listening to quality pop-rock, like La Unión, Danza Invisible..., I went to listening to empty melodies lacking in harmony, in which the only thing that mattered was the feeling of love that they were trying to convey. I didn't like them and I still don't. [...]. Nowadays, I consider myself a music-lover, I adore music and for me a day without listening to anything new is a day wasted. There is so much music and so much good music, that it really annoys me to think that if I started listening to everything I own without interruption, I wouldn't have the time, even if I lived a hundred years (J.-C. A.-L, October $8^{\text {th }}, 2013$ ).

5. There are no evident differences in gender in the micro-tales, although there are generational ones - the older students are more creative due to their own life-musical trajectory and communicative capacities_- Despite our initial idea, geographical origins are almost irrelevant, 
with the exception of references to traditional rustic images (see Testimony 6). It is also interesting to highlight the demystification in some cases of the common dichotomy established between the quietness of the village and the sound pollution of the city (see Testimony 7).

\section{Testimony 6}

Every day, I used to listen to the sound of the church bell in my village which is in the center of the square and flooded the entire village and, sometimes, would be premonitory [...] (J. P.-P., October $8^{\text {th }}, 2013$ ).

\section{Testimony 7}

I loved the arrival of night to see towns and cities lit up and at bed time to listen to the fast noises of the cars, and from this began one my passions, which continues to be big cities with their racket and their lights at night (A. R.-L, October 10 $0^{\text {th }}, 2013$ ).

6. Beyond the purely musical aspects, the tales also show some features of the student's personality (decision-making, introversion, self-confidence, creativity, de-motivation, friendliness, gravity, sensitiveness, fragility, responsibility), which are projected in certain discursive decisions, from the choice of the subject narrator (most of them did it in first person, although others preferred an omniscient external narrator in third person - see Testimony 8-), to the way of presenting the text (flat reading or dramatized, use of body language), without forgetting the establishment of descriptive limits or a 'descriptive auto-censorship' (some of them reveal very intimate moments of their lives — see Testimony 9-).

\section{Testimony 8}

A little over 24 years ago, in Orihuela, a baby girl was born, who mysteriously loved to sleep surrounded by a lot of noise [...] (L. R.-B., October $8^{\text {th }}$, 2013).

\section{Testimony 9}

From this love I remember that, when I would leave her late at her house, taking advantage of the fact that her parents were in bed, I would slyly sneak into her room, and the alarm clock that would wake me up to run out of there was a neighbor's rooster [turkey], with its characteristic glu g/u (J.-C. A.-L, October $\left.10^{\text {th }}, 2013\right)$. 


\section{Final Thoughts: Implications for Music Teacher Education}

This study is set in the new learning culture based on emotions and technologies, where the image, in cooperation with the sound element, gains considerable relevance. Therefore, it has nothing to do with the reinforcement of emotions in the classroom, but with teaching with emotion, since it transmits sense to the content.

In this frame, the work shed light on the formation process of the ego and the interaction of the group "face to face". The student body performed a reflection exercise and self-discovery that not only provided them with a more suited image of themselves, but also enabled the construction of the group-class and their position or role within it (e.g. leader, sociable, collaborator, pessimistic, passive, critical, defiant, systematic opponent, isolated). Despite some initial reservations - there were people who refused to present their micro-tale in public - the outcome was highly positive, creating in the classroom an environment of integration, interaction, trust, empathy, and respect. To achieve this, the teachers acted as moderators and encouraged ideas at all times, blurring their traditional privileged position. On the other hand, the students became aware that music had been decisive in the configuration of their identities, which relieved initial fears and prejudices towards the subject and encouraged them to approach it with greater optimism.

It has been evinced that this research has direct implications for teacher trainers. Approaching students through their own micro-tales has proved to be a useful teaching strategy on several fronts. To begin with, it has positively contributed to the management and moderation of the classroom and to the resolution of possible tensions and resilience towards a new subject.

To conclude, the audiovisual micro-tale acquires a special meaning for music teachers as well as for students. What are the reasons for this?

- Educators make the musical past of the participants emerge in order to generate an individual and collective musical memory within a specific learning background. That is how students either familiarize with different sound realities from theirs, or they identify themselves among others'.

- It supports the construction of values, beliefs and attitudes towards music, as well as its cross-curricular and transdisciplinary treatment, since it connects verbal, non-verbal and audiovisual language. 
Thereby, the communicative power of words alone (logocentrism) becomes relative in the present-day classrooms faced to sensorial aspects.

- Students become aware of the music significance for the development of both their personal and professional identity.

- It strengthens the development of students' artistic creativity.

Due to all these reasons, we advise to include audiovisual micro-tales in the first lessons of musical subjects, not only within university levels, but it could also be adapted to other educational levels and contexts with learning difficulties arising from problems of self-perception (feeling of failure or inability, low self-esteem and frustration) and social coexistence (lack of communication and cultural differences, segregation and discrimination in the peer group). In this way, "it is possible to educate in the communicative encounter with others from a dialogic and intersubjective interpretation of reality" ${ }^{3}$ (De las Heras, 2011, cit. by Ballesta, 2012, p. 354).

\section{Author Note and Ackknowledgements}

This study has received assistance from the Research Group 'Music and Cultural Studies' and the Area of Didactic of Music of the Department of Music, Visual Arts and Physical Education at the University of Jaén. The authors thank students of the Bachelor's Degree in Primary Education (course 2013-2014) their participation in the project and their colleagues Javier Marín-López, Marisa Pérez-Cañado, Ma Manuela Merino-García and Víctor Yanes-Córdoba the assistance provided in the proof review.

\section{References}

Aguirre, I. (2003). Estudio de los imaginarios visuales y musicales de los estudiantes de secundaria en Navarra: aplicaciones educativas, Research Project. Government of Navarra, Spain.

Ayala, I., \& Castillo, M. (2008). Música, interdisciplinariedad e inclusión social. El friso

3 Own translation of the original Spanish text: "[...] desde una interpretación dialógica e intersubjetiva de la realidad se puede educar en el encuentro comunicativo con los otros" (De las Heras, 2011, cit. en Ballesta, 2012, p. 354). 
Identidades reflexivas en la universidad: sonidos, imágenes y microrrelatos autobiográficos

Isabel María Ayala Herrera y Virginia Sánchez López

sonoro como propuesta de aplicación en el aula. In M. L. Zagalaz \& A. M. Ribeiro (Eds.), Atividades lúdicas em contextos culturais: interdisciplinaridade e inclusão (pp. 127-136). Capivari de Baixo, Brazil: FUCAP.

Ballesta, J. (2012). Bautista, A. y Velasco, H. (Coord.) (2011). Antropología audiovisual: medios e investigación en educación. Madrid: Editorial Trotta. Educatio Siglo XXI, 30(1), 353-356.

Bond, V. L., \& Huisman Koops, L. (2014). Together Through Transitions: A Narrative Inquiry of Emergent Identity as Music Teacher Educators. Journal of Music Teacher Education, 24(I), 38-50. doi:10.1177/1057083713494012

Chion, M. (1993). La audiovisión. Introducción a un análisis conjunto de la imagen y el sonido. Barcelona: Paidós Ibérica.

Clandinin, D. J., \& Connelly, F. M. (2000). Narrative inquiry: Experience and story in qualitative research. San Francisco: Jossey-Bass.

Díaz, M., \& Giráldez (coords.) (2013). Investigación cualitativa en educación musical. Barcelona: GRAÓ.

Guarinos, V., \& Gordillo, I. (2010). El microrrelato audiovisual como narrativa digital necesaria. CISCI 2010. IX Conferencia Iberoamericana en Sistemas, Cibernética e Informática (vol. 291). Orlando, FL: CISCI. Retrieved from http://www.iiis.org/CDs2010/CD2010CSC/SVD_2010/PapersPdf/OB090CP.pdf

Ibarretxe, G. (2006). Imaginarios e identidad juvenil en contextos cotidianos de educación musical. Eufonía. Didáctica de la Música, 38, 73-86.

Izquierdo-Magaldi, B., Lacasa, P., \& Castillo, H. (2014). 'Teaching between the lines': discussing, interpreting and writing stories together. Culture and education, 26(3), 535-556. doi: 10.1080/11356405.2014.965447

Jones, B. D., \& Parkes, K. A. (2010). The Motivation of Undergraduate Music Students: The Impact of Identification and Talent Beliefs on Choosing a Career in Music Education. Journal of Music Teacher Education, 19(2), 41-56. doi:10.1177/1057083709351816

Jorgensen, E. R. (2009). On thick description and narrative inquiry in music education. Research Studies in Music Education, 31(1), 69-81. doi: 10.1177/1321103X09103632

Kallio, A. A. (2015). Factional stories: Creating a methodological space for collaborative reflection and inquiry in music education research. Research Studies in Music Education, 37(1), 3-20. doi: 10.1177/1321103X15589261

Lagmanovich, D. (2006). El microrrelato: teoría e historia. Palencia: Menoscuarto.

Marcellan-Baraze, I., Calvelhe, L., Aguirre, I., \& Arriaga, A. (2013). Estudio sobre jóvenes productores de cultura visual: evidencias de la brecha entre la escuela y la juventud. Arte, Individuo y Sociedad, 25(3), 524-535. doi: 10.5209/rev_ARIS.2013.v25. n3.40752

Martínez-Iglesias, J. (2011). Cultura visual e imaginarios juveniles: una investigación narrativa. In F. Hernández (Coord.), Investigar con los jóvenes: cuestiones temáticas, metodológicas, éticas y educativas (pp. 124-132). Barcelona: Universitat, EsbrinaRecerca. Retrieved from http://hdl.handle.net/2445/17362/

Navarro, R. M. (2014). Literatura breve en la red: el microrrelato como género transmediático. Tonos digital: Revista electrónica de estudios filológicos, 27, 1-12. Retrieved from 
Identidades reflexivas en la universidad: sonidos, imágenes y microrrelatos autobiográficos

Isabel María Ayala Herrera y Virginia Sánchez lópez

https://digitum.um.es/xmlui/bitstream/10201/40426/1/Literatura\%20breve\%20 en\%20la\%20red.pdf/

Ocaña, A. (2006). Identidad y ciclos de desarrollo profesional de los maestros y maestras de Educación Musical, PhD. Granada: Universidad.

Odena, O. (2015). La investigación en educación musical dentro de las Ciencias Sociales: reflexiones desde el Reino Unido. Revista Electrónica Complutense de Investigación en Educación Musical, 12, 1-10. doi: 10.5209/revRECIEM.2015.v12.49141

Porta, A. (2014). La construcción de la identidad en la infancia y su relación con la música: un acercamiento a través del análisis cualitativo de los Media. Dedica. Revista de Educação e Humanidades, 5, 71-76. Retrieved from http://hum742.ugr.es/seccion_libre/dedica-revista-de-educao-e-humanidades/

Pujadas, J. J. (1992). El método biográfico: el uso de las historias de vida en Ciencias Sociales. Madrid: CIS.

Rockwell, E. (1986). Etnografía y teoría en la investigación educativa. In Enfoques. Cuadernos del Tercer Seminario Nacional de Investigación en Educación. Bogotá: Centro de Investigación de la Universidad Pedagógica.

Sancho, J., Hernández, F., Herráiz, F., \& Vidiella, J. (2009). Una investigación narrativa en torno al aprendizaje de las masculinidades en la escuela. Revista Mexicana de Investigación Educativa, 14(43), 1155-1189. Retrieved from http://www.scielo.org. $\mathrm{mx} / \mathrm{pdf} / \mathrm{rmie} / \mathrm{v} 14 \mathrm{n} 43 / \mathrm{v} 14 \mathrm{n} 43 \mathrm{a} 8 . \mathrm{pdf} /$

Valles, J. R. (2008). Teoría de la narrativa: una perspectiva sistemática. Madrid: Iberoamericana.

Van Dijk, T. A. (2003). El discurso como estructura y proceso. Estudios sobre el discurso: una introducción multidisciplinaria (vol. I). Barcelona: Gedisa.

Woods, P. (1986). Inside Schools: Ethnography in Educational Research. London: Routledge \& Kegan Paul.

Yanes, V. R. (2007). La narrativa visual como metodología del sentido: articulación metodológica e implicaciones terapéutico-educativas. Arteterapia, 2, 233-246. 
